\title{
Effect of Linseed Meal on Broiler Performance and Fat Content
}

\author{
Meherunnisa Leghari ${ }^{1}$, Imdad Hussain leghari ${ }^{2}$, Abdullah Sethar ${ }^{3 *}$, Gul Hassan Sethar ${ }^{4}$ and Farzana Manzoor Sethar $^{5}$ \\ ${ }^{1}$ Livestock Department, Government of Sindh, Pakistan
}

${ }^{2}$ Department of Poultry Husbandry, Sindh Agriculture University, Pakistan

${ }^{3}$ Shaheed Benazir Bhutto University of Veterinary \& Animal Sciences, Pakistan

${ }^{4}$ Health Department, Government of Sindh, Pakistan

${ }^{5}$ Writer, Pakistan

Submission: August 14, 2017; Published: October 02, 2017

*Corresponding author: Abdullah Sethar, Assistant Professor, Shaheed Benazir Bhutto University of Veterinary \& Animal Sciences, Sakrand, District Shaheed Benazirabad, Sindh, Pakistan, Tel: +92(0)3002710093; Email: drabdullahsethar@hotmail.com

Abstract

An experiment was conducted to determine the optimum level of linseed meal in broiler ration. For this purpose 200 day old chicks were reared for 42 days and were divided into five equal groups and fed $0 \%, 5 \%, 10 \%, 15 \%$ and $20 \%$ of linseed meal, respectively. All these rations were treated with water at $37^{\circ} \mathrm{C}$ for 24 hours to reduce the cyanide toxicity. The following observation were recorded which are given below; weight gain at 42 days, feed consumption at 42 days, Feed Conversion Ratio (FCR), carcass weight, weight of giblets, economic.

Results revealed significant differences $(\mathrm{P}>0.05)$ for weight again among different groups. The total weight gains of the groups $\mathrm{A}, \mathrm{B}, \mathrm{C}, \mathrm{D}$ and E were 1801, 1830, 1875, 1903 and 1872g, respectively. Group D was significantly heavier than all the other groups. Total feed consumption in group A, B, C, D and E showed significantly greater difference. Total feed consumption of broiler in groups A, B, C, D and E were 3633, 3425, 3356, 3214 and $3601 \mathrm{~g}$, respectively. The maximum feed was consumed by chicks in group E. Total feed conversion ratio of chicks in group A, B, C, D and $\mathrm{E}$ were $2.01,1.87,1.78,1.68$ and 1.93, respectively. The chicks in group D were significantly different in feed utilization than the chicks in the other groups. The carcass weights of chicks in group A, B, C, D and E were 1161, 1215, 1227, 1243 and 1238g, respectively. The chicks in group "D" gave significantly more carcass weight as compared to other groups. However non-significant differences were observed in the weights of giblets (Liver, Gizzard, Spleen and Heart). It was concluded that broilers can be reared economically by using $15 \%$ linseed meal treated with water at 37

${ }^{\circ} \mathrm{C}$ for 24 hours in poultry ration.

\section{Introduction}

Poultry industry in Pakistan has been facing serious problems since the recent past due to growing size of the industry. Current constraints of poultry industry includes; high production costs, increased prices of feed, medicine, construction, maintenance, equipments, day old chicks and labor charges; fluctuating prices of poultry products due to seasonal changes, lack of skill due to poor educational facilities; unorganized marketing facilities due to monopoly of middlemen and big farmers, lack of grading, processing, storage facilities, lack of consumers knowledge about quality poultry products; higher mortality rate in flocks due to poor quality of day old chicks and incidence of unidentified disease. Among all these problems increasing costs and low quality feed are the most serious problems. As feed comprise more than $70 \%$ of total investment of the farming and is also a fact that the cost and quality of feed depends on the cost and quality of its ingredients, thus the more cheaply and qualitative ingredients, the cheaper and qualitative will be the feed.
At present Pakistan is importing soybean meal from outside country due to being a rich source of crude protein it is used as an ingredient in the poultry feed. In spite of being qualitative it is costlier and is adding extra burden on the already indebted falling economy of Pakistan, thus it is imperative for us to search out cheaper, qualitative and local alternatives. In this respect, linseed meal which is abundantly available in Sindh and is being used for livestock feeding will be used for its effects on the broiler growth after treating it.

Linseed meal is the secondary product of oil extraction from linseeds (Linum usitatissimum L.). Linseeds and its byproducts have attracted considerable attention since the 1990s because of the presence of Poly Unsaturated Fatty Acids (PUFA), omega-3 fatty acid and Conjugated Linoleic Acid (CLA). Provision of these fatty acids to the rations of animals is being practiced to change the FA content of meat, milk and eggs for their consumers. In addition to this these have laxative properties and good effects on 
the appearance of skin and hair (Altsuhul [1]; Altsuhul et al., [2]). Moreover, Linseeds contain lignans, which act in mammalians as phytoestrogens and have anti-carcinogenic properties (Bafundo [3]). Linseeds are abundant in oil but their extraction is difficult and often requires double pressing. The seeds are first soaked to reduce the making of fine particles and then passed through sets of corrugated and smooth rollers to be cracked and flaked, respectively. Finally, when linseeds are pressed for food oil production, extraction is performed with cold pressing (oil temperature below $35{ }^{\circ} \mathrm{C}$ ), and in the result significant amount of residual oil (about 10\%) is left in linseed meal. In addition to this for toxic removal the moisturized and flaked seeds are sent to a cooker where they are subjected to a temperature of $80-100^{\circ} \mathrm{C}$ to inactivate enzymes and ease the release of oil during pressing. The cooked seeds are transferred to the expeller for mechanical extraction, and the resulting cake is fed to the solvent (hexane) extractor. The solvent-extracted cake is desolventized at $100{ }^{\circ} \mathrm{C}$ and then cooled [4]. Linseed meal consists of dark grey pieces (flakes) of different size with a smooth, slightly curved cut surface [5]. Unlike other major meals (soybean, sunflower and rapeseed), the major source of linseed meal available for livestock feeding is the oil-rich expeller type rather than solventextracted meal, which is less commonly used [6]. Linseed oil is a rich source of linolenic acid which may be used into the meat and eggs of birds to which it is fed. The total omega- 3 fatty acids are enhanced in these poultry products.

Thus, the present study has been designed to find the potential use of linseed meal in the poultry industry for the growth performance.

\section{Materials and Methods}

Table 1: Composition of Five-Starter Ration (\%).

\begin{tabular}{|c|c|c|c|c|c|}
\hline SINGREDIENTS & A & B & C & D & E \\
\hline Maize & 56.5 & 56.5 & 56.5 & 56.5 & 56.5 \\
\hline Soybean meal & 20 & 13.5 & 9.5 & 5 & 3 \\
\hline Guar meal & 2 & 5 & 5 & 6 & 3 \\
\hline Linseed meal & 0 & 5 & 10 & 15 & 20 \\
\hline Fish meal & 5 & 5 & 5 & 5 & 5 \\
\hline Meat meal & 8 & 8 & 8 & 8 & 8 \\
\hline What Broken & 7 & 5.5 & 4.5 & 3 & 3 \\
\hline D.C.P & 1 & 1 & 1 & 1 & 1 \\
\hline Vitamin Premix & 0.5 & 0.5 & 0.5 & 0.5 & 0.5 \\
\hline Total & 100 & 100 & 100 & 100 & 100 \\
\hline
\end{tabular}

The experiment was conducted at the Poultry Experimental Station, Department of Poultry Husbandry, Faculty of Animal Husbandry and Veterinary Science, Sindh Agriculture University, Tando Jam during months of February- March 2000. Two Hundred numbers of day old broiler (Hubbard) chicks were purchased from the local market. The experiment continued for 6 weeks. All the chicks were weighed individually at the start of experiment and were randomly divided into five groups of 40 chicks each. The chicks were kept on deep litter system by using sawdust.
The shed was whiting washed and disinfected thoroughly before the arrival of chicks. Feed ingredients used in the ration were purchased from local market. Five experimental rations were prepared and designated as A, B, C, D and E for starter (s 1) and finisher ration (Table 1\&2). The following treatments were given (Table 3).

Table 2: Composition of Five Finisher Rations (\%).

\begin{tabular}{|c|c|c|c|c|c|}
\hline & A & B & C & D & E \\
\hline Crude Protein & $23-00$ & 22.8 & 22.7 & 22.6 & 22.5 \\
\hline Crude fiber \% & 3.5 & 3.3 & 3.2 & 3.1 & 3.1 \\
\hline E.E \% & 8.3 & 8.7 & 9 & 9 & 9 \\
\hline M.E.Kcal/Kg & 3025 & 2960 & 2955 & 2947 & 2938 \\
\hline Calcium & 1.23 & 1.2 & 1.19 & 1.17 & 1.16 \\
\hline Phosphorus & 0.5 & 0.5 & 0.5 & 0.5 & 0.5 \\
\hline
\end{tabular}

Table 3:

\begin{tabular}{|c|c|c|c|c|c|c|}
\hline M.E (Kcal/kg) & D.M & C.P & C.F & E.E & NFE & Total Ash \\
\hline 2200 & 94 & 29.6 & 11.1 & 10.4 & 42.6 & 6.3 \\
\hline
\end{tabular}

The Temperature of the all compartments was maintained in such a way that it was $95^{\circ} \mathrm{F}$ in the 1 st week and was reduced by 5 ${ }^{\circ} \mathrm{F}$ every coming week until it reached $70^{\circ} \mathrm{F}$ which was maintained throughout the rest of experimental period. Continuous light was provided throughout the conduct of experiment. The birds were fed ad libitum throughout the period of experiment. Fresh and clean water was also provided round the clock. All the birds were vaccinated accordingly.

Table 4: Chemical Composition of Linseed Meal.

\begin{tabular}{|c|c|c|c|c|c|c|}
\hline M.E (Kcal/kg) & D.M & C.P & C.F & E.E & NFE & Total Ash \\
\hline 2200 & 94 & 29.6 & 11.1 & 10.4 & 42.6 & 6.3 \\
\hline
\end{tabular}

The following observation were recorded which are given below: weight gain at 42 days, Feed consumption at 42 days, Feed Conversion Ratio (FCR), carcass weight, weight of giblets (Liver, gizzard, heart and spleen, Fat pad, meat quality for rancidity, Economics. At the end of experiment five birds from each group were randomly selected and slaughtered to study the carcass weight and weight of internal organs. The data thus collected was statistically analyzed by using analysis of variance technique (ANOVA) on M STAT-C program on computer Table 4.

\section{Results and Discussion}

\section{Weight gain}

The average total weight gains of broilers in groups. A, B, C, D and E were 1801, 1830, 1875, 1903 and 1873g, respectively (Table 5). The highest weight gain was observed in-group " $D$ " (1903g), while lowest weight gain was observed in-group " $\mathrm{A}$ " (1801g). The data when subjected to statistical analysis of variance showed highly significant $(\mathrm{P}<0.01)$ differences in the weight gains among different groups. For further comparison of means LSD test was applied which showed that the group " $D$ " was highly significantly $(\mathrm{P}<0.01)$ greater weight than the remaining groups $\mathrm{C}, \mathrm{E}, \mathrm{B}$ and A respectively. This shows that our results 
are in confirmation with Liversidge et al. [7] who suggested that cyanide toxicity can be reduced and linseed meal can be used effectively at the level of more than $5 \%$ if linseed meal is soaked in water for 24 hours at $37^{\circ} \mathrm{C}$.

Table 5: Comparison of Means by LSD Test.

\begin{tabular}{|c|c|c|c|c|c|c|}
\hline \multirow{2}{*}{ Rations } & \multirow{2}{*}{ Means } & \multicolumn{5}{|c|}{ Difference of Means } \\
\cline { 3 - 7 } & & $\mathrm{D}$ & $\mathrm{E}$ & $\mathrm{C}$ & $\mathrm{B}$ & $\mathrm{A}$ \\
\hline $\mathrm{D}$ & 1903 & - & $28^{* *}$ & $30^{* *}$ & $73^{* *}$ & $102^{* *}$ \\
\hline $\mathrm{E}$ & 1875 & - & - & $02 \mathrm{NS}$ & $45^{* *}$ & $74^{* *}$ \\
\hline $\mathrm{C}$ & 1873 & - & - & - & $43^{* *}$ & $72^{* *}$ \\
\hline $\mathrm{B}$ & 1830 & - & - & - & - & $29^{* *}$ \\
\hline $\mathrm{A}$ & 1801 & - & - & - & - & - \\
\hline
\end{tabular}

$\mathrm{P}<0.05$ significant figures are expressed with*

\section{Feed Consumption}

Table 6: Comparison of means.

\begin{tabular}{|c|c|c|c|c|c|c|}
\hline \multirow{2}{*}{ Rations } & \multirow{2}{*}{ Means } & \multicolumn{5}{|c|}{ Difference of Means } \\
\cline { 3 - 7 } & & D & E & C & B & A \\
\hline D & 3214 & - & $13 N S$ & $27^{* *}$ & $38^{* *}$ & $46^{* *}$ \\
\hline E & 3355 & - & - & 14 & $25^{* *}$ & $33^{* *}$ \\
\hline C & 3425 & - & - & - & 11 NS & $19^{* *}$ \\
\hline B & 3604 & - & - & - & - & $08 \mathrm{NS}$ \\
\hline A & 3633 & - & - & - & - & - \\
\hline
\end{tabular}

The average feed consumption by broilers in groups A, B, C, D and $E$ were $3633,3425,3356,3214$ and 3601 grams respectively. The maximum feed (3633g) was consumed by group E, while minimum feed (3214g) was consumed by group D. The data when subjected to analysis of variance showed highly significant differences $(\mathrm{P}<0.01)$ in the feed consumption among different groups. For further comparison, LSD test was applied which showed that there was a highly significant difference in-group E as compared to other groups. However, there was significant difference between group A\&D and non-significant difference was observed between group E\&C, C\&D as well as B\&A. Thus group E consumed more feed as compared to group C, D, B and A respectively. The results of feed consumption during starter period showed that chicks fed on ration A consumed more feed when compared to all other rations Table 6.

\section{Feed Efficiency}

At the end of experiment the overall feed efficiency value of broilers reared on different starter and finisher rations A,B,C,D and E were 2.01, 1.87, 1.78, 1.68 and 1.93 respectively (Table 7). The birds fed on ration " $D$ " were apparently the most efficient in feed utilization while other birds fed on ration "A" were the least efficient in feed utilization. The data when subjected to analysis of variance revealed highly significant $(\mathrm{P}<0.01)$ in feed efficiency values among different groups. For further comparison of means LSD test was applied Table 8 which revealed that birds in group " $D$ " were better efficient that the birds in group C,E,B and A respectively. Our results are in confirmation with who reported that water treated linseed meal is more efficient as competed to non-water treated linseed meal. Lopez-Ferrer et al. [8] also suggested that non-water treated linseed meal is detrimental to chicks if it is given at $4.5 \%$ or more, therefore it is better to treat linseed meal with water Table 7.

Table 7: Comparison of FCR means.

\begin{tabular}{|c|c|c|c|c|c|c|}
\hline \multirow{2}{*}{ Rations } & \multirow{2}{*}{ Means } & \multicolumn{5}{|c|}{ Difference of Means } \\
\cline { 3 - 7 } & & $\mathrm{A}$ & $\mathrm{B}$ & $\mathrm{E}$ & $\mathrm{C}$ & $\mathrm{D}$ \\
\hline $\mathrm{D}$ & 2.01 & - & $0.04^{* *}$ & $0.06^{*}$ & $0.07^{* *}$ & $0.11^{* *}$ \\
\hline $\mathrm{E}$ & 1.87 & - & - & $0.02^{*}$ & $0.03^{* *}$ & $0.07^{* *}$ \\
\hline $\mathrm{C}$ & 1.78 & - & - & - & $0.01 \mathrm{NS}$ & $0.05^{* *}$ \\
\hline $\mathrm{B}$ & 1.68 & - & - & - & - & $0.04^{* *}$ \\
\hline $\mathrm{A}$ & 1.93 & - & - & - & - & - \\
\hline
\end{tabular}

$\mathrm{P}<0.05$ significant figures are expressed with*

Table 8: Total feed conversion ratio of broilers.

\begin{tabular}{|c|c|c|c|}
\hline Groups & $\begin{array}{c}\text { Feed consumed per } \\
\text { chick(g) }\end{array}$ & $\begin{array}{c}\text { Weight gain } \\
\text { per chick(g) }\end{array}$ & Total FCR \\
\hline A & 3633 & 1801 & 2.01 \\
\hline B & 3425 & 1830 & 1.87 \\
\hline C & 3355 & 1875 & 1.78 \\
\hline D & 3214 & 1903 & 1.68 \\
\hline E & 3601 & 1872 & 1.93 \\
\hline
\end{tabular}

\section{Weight of carcass}

Table 9: Comparison of means carcass weight among the groups.

\begin{tabular}{|c|c|c|c|c|c|c|}
\hline \multirow{2}{*}{ Rations } & \multirow{2}{*}{ Means } & \multicolumn{5}{|c|}{ Difference of Means } \\
\cline { 3 - 7 } & & $\mathrm{A}$ & $\mathrm{B}$ & $\mathrm{C}$ & $\mathrm{E}$ & $\mathrm{D}$ \\
\hline $\mathrm{D}$ & 1243 & - & $0.04 \mathrm{NS}$ & $16 \mathrm{NS}$ & $28^{* *}$ & $82^{* *}$ \\
\hline E & 1238 & - & - & $11 \mathrm{NS}$ & $23 \mathrm{NS}$ & $77^{* *}$ \\
\hline C & 1227 & - & - & - & $12 \mathrm{NS}$ & $66^{* *}$ \\
\hline B & 1215 & - & - & - & - & $54^{* *}$ \\
\hline A & 1161 & - & - & - & - & - \\
\hline
\end{tabular}

$\mathrm{P}<0.05$ significant figures are expressed with*

The average values for carcass weight of broilers in group A, B, C, D and E were 1161, 1215, 1227, 1243 and 1238 grams, respectively. Thus group " $\mathrm{D}$ ” obtained maximum carcass weight and group A obtained minimum crass weight. The data when subjected to analysis of variance showed highly significant differences $(\mathrm{P}<0.01)$ among different groups. For further comparison LSD test was applied which revealed that group "D" gained better carcass weight as compared to B,C,E and D respectively. However, there was significant difference between $B \& D$ and non-significant difference between D\&E, D\&C, E\&C, $\mathrm{E} \& \mathrm{~B}$ as well as $\mathrm{C} \& \mathrm{~B}$, respectively. It shows that linseed meal affects the muscular growth of the body Table 9 .

\section{Weight of Giblets}

The average weight of liver of broiler chicks fed on different experimental ration A,B,C,D and E were 45.22, 45, 46, 45.28, 45.91 and $45.22 \mathrm{~g}$ respectively. The data when subjected to 
statistical analysis showed non-significant differences in the weight of liver of broilers fed on different experimental ration. The results indicated that liver was not affected by increasing the level of linseed meal. The average weight of gizzard of broiler chicks fed on experimental rations A, B, C, D and E was $34.64,35.46,36.16,35.94$ and $35.84 \mathrm{~g}$, respectively. The data when subjected to statistical analysis of variance showed nonsignificant differences in the weights of gizzards of different groups Roth-Maier [9]. The average weight of heart of broiler in group A, B, C, D and E was 7.8, 7.7, 8.0, 4.4 and 8.2g, respectively. The data when subjected to statistical analysis showed nonsignificant differences in the weight of heart of different groups. The average weight of spleen in groups A, B, C, D and E was 2.02, $2.48,2.51,2.75$ and $2.23 \mathrm{~g}$ respectively (Table 10 \&11). The data when subjected to statistical analysis of variance showed nonsignificant difference in different groups. Thus spleen was not affected.

Table 10: Summary of weight of giblet (gm).

\begin{tabular}{|c|c|c|c|c|}
\hline Ration & Liver & Gizzard & Heart & Spleen \\
\hline A & 45.22 & 34.64 & 7.8 & 2.02 \\
\hline B & 45.46 & 35.43 & 7.7 & 2.48 \\
\hline C & 45.28 & 36.16 & 8 & 2.51 \\
\hline D & 45.91 & 35.94 & 8.4 & 2.75 \\
\hline E & 45.22 & 35.84 & 8.2 & 2.23 \\
\hline
\end{tabular}

Table 11: Economics of experimental ration.

\begin{tabular}{|c|c|c|c|c|c|}
\hline Observations & A & B & C & D & E \\
\hline $\begin{array}{c}\text { Total weight gain/bird } \\
\text { (kg) }\end{array}$ & 1892 & 1865 & 1885 & 1866 & 1880 \\
\hline $\begin{array}{c}\text { Per Kg cost of } \\
\text { production (Rs) }\end{array}$ & 128 & 120 & 115 & 111 & 120 \\
\hline $\begin{array}{c}\text { Total cost of production } \\
\text { / bird }\end{array}$ & 245 & 223 & 216 & 207 & 225 \\
\hline $\begin{array}{c}\text { a. Sale price of per kg } \\
\text { live bird (Rs) }\end{array}$ & 130 & 130 & 130 & 130 & 130 \\
\hline b. Total Profit / Bird (Rs) & 15 & 37 & 44 & 53 & 35 \\
\hline
\end{tabular}

\section{Economics}

Table 12: Composition of Five Finisher Rations (\%).

\begin{tabular}{|c|c|c|c|c|c|}
\hline & A & B & C & D & E \\
\hline Crude Protein & $23-00$ & 22.8 & 22.7 & 22.6 & 22.5 \\
\hline Crude fiber \% & 3.5 & 3.3 & 3.2 & 3.1 & 3.1 \\
\hline E.E \% & 8.3 & 8.7 & 9 & 9 & 9 \\
\hline M.E.Kcal/Kg & 3025 & 2960 & 2955 & 2947 & 2938 \\
\hline Calcium & 1.23 & 1.2 & 1.19 & 1.17 & 1.16 \\
\hline Phosphorus & 0.5 & 0.5 & 0.5 & 0.5 & 0.5 \\
\hline
\end{tabular}

The net profit bird in each group was Rs 15,37,44,53 and 35 respectively (Table $12 \& 13$ ). Results indicated that the rations containing $15 \%$ of water treated linseed meal was most economical than other rations C, E, B and A respectively. Ration "D" was cheapest while A was the most expensive. So it was feasible to increase water treated linseed meal up to $15 \%$ level in the broiler ration.

Table 13: Chemical Composition of Five-Starter Ration (\%).

\begin{tabular}{|c|c|c|c|c|c|}
\hline Ingredients & A & B & C & D & E \\
\hline Maize & 58 & 58 & 58 & 58 & 58 \\
\hline Soybean meal & 15 & 11 & 7 & 2 & - \\
\hline Guar meal & 5 & 5 & 5 & 5 & 5 \\
\hline Linseed meal & - & 5 & 10 & 15 & 20 \\
\hline Fish meal & 5 & 5 & 5 & 5 & 5 \\
\hline Meat meal & 8 & 8 & 8 & 8 & 8 \\
\hline Wheat Broken & 7 & 6 & 5 & 5 & 5 \\
\hline D.C.P & 1.5 & 1.5 & 1.5 & 1.5 & 1.5 \\
\hline Vitamin & Premix & 0.5 & 0.5 & 0.5 & 0.5 \\
\hline Total & 100 & 100 & 100 & 100 & 100 \\
\hline
\end{tabular}

\section{References}

1. Altsuhul AM, Curet ME, Karon ML, Hall Catherine, Smith BA (1956) The storage of Cottonseed V.Mill-scale test on the effects of Various Treatments of Cottonseed and Flaxseed on Heating and free Fatty Acid Formation durng Starage. Oil Mill Gazeteer 50: 9-13, 23.

2. Altschul AM, Karon ML, Schaefer HC (1948) Note on Effect on Chick Growth of Feeding Meals Prepared from Flaxseed and Cottonseed Treated with Ammonia Prior to Storage. Poul Sci 27(4): 408-410.

3. Bafundo KN, GM Ellis (1977) The comparative study of linseed meal with rapeseed meal. Poul Science 71(5): 850-858.

4. Ishibashi, Ueno (1984) Replacement of linseed meal with cotton seed meal. Animal Science and Technology Journal 37 (1): 145-156.

5. Kratzer FH (1946) The Treatment of Linseed Meal to Improve its Feeding Value for Chicks*. Poul Sci 25: 541-542.

6. Kratzer FH, Williams D, Baker EF (1947) Amino acids required to supplement linseed protein for chick growth. J Nut 33(3): 313-318.

7. Liversidge RM, Lloyd GJ, Wase DAJ, Forster CF (1997) Removal of basic blue 41 dye from aqueous solution by linseed cake. Process Biochemistry 32(6): 473-476.

8. Lopez-Ferrer S, Baucells MD, Barroeta AC, Grashorn MA (1999) Influence of linseed oil sources on quality parameters of broiler meat. Archiv fur Geflugelkunde 63(1): 29-35.

9. Roth-Maier DA, Eder K, Kirchgessner M (1998) Live performance and fatty acid composition of meat in broiler chickens fed diets with various amounts of ground or whole flaxseed. Journal of Animal Physiology \& Animal Nutrition-Zeitschrift fur. Tierphysiologie Tierernahrung and Futtermittelkunde 79(1-5): 260-268. 
This work is licensed under Creative Commons Attribution 4.0 Licens

DoI: 10.19080/JDVS.2017.04.555628
Your next submission with Juniper Publishers will reach you the below assets

- Quality Editorial service

- Swift Peer Review

- Reprints availability

- E-prints ServiceManuscript Podcast for convenient understanding

- Global attainment for your research

- Manuscript accessibility in different formats

( Pdf, E-pub, Full Text, Audio)

- Unceasing customer service

Track the below URL for one-step submission https://juniperpublishers.com/online-submission.php 